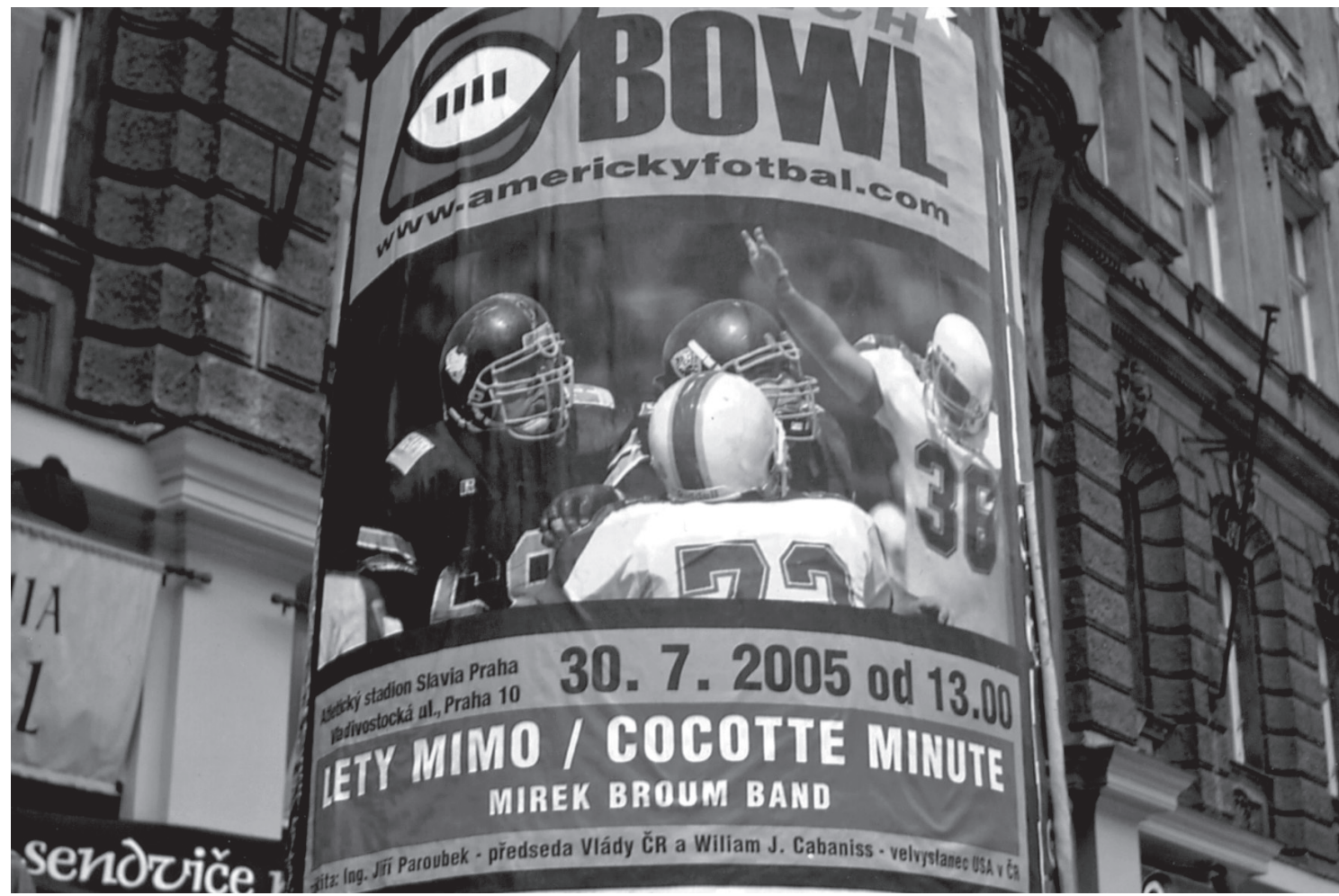

\title{
The Political Uses of Sport by the United States
}


Politics in the United States can be puzzling and ironic, often clouded by factors of race, religion, and commerce. The United States preaches an idealistic doctrine in its tenets of democracy, equality, and liberty; but takes a more pragmatic approach in its foreign policies and its application of sport as a political means to achieve its ends. At times it has even enacted the Marxist praxis of sport as a means of social control or the hegemonic practices of Gramscian theory to assimilate immigrant groups or coerce colonized peoples into its prescribed value systems that promote capitalism and a white, Protestant form of Christianity. The pattern of sport as a correlate to diplomacy has been evident for more than a century, as will be shown by the following examination.

\section{SPORT IN THE UNITED STATES: ORGANIZATION, PURPOSES, AND A BRIEF HISTORY}

Unlike European notions of sport for all, sports in the United States are generally organized in an elitist framework, whereby only the best athletes at each level can continue to play at the highest (professional) levels; while most others are relegated to roles as spectators. The conse-

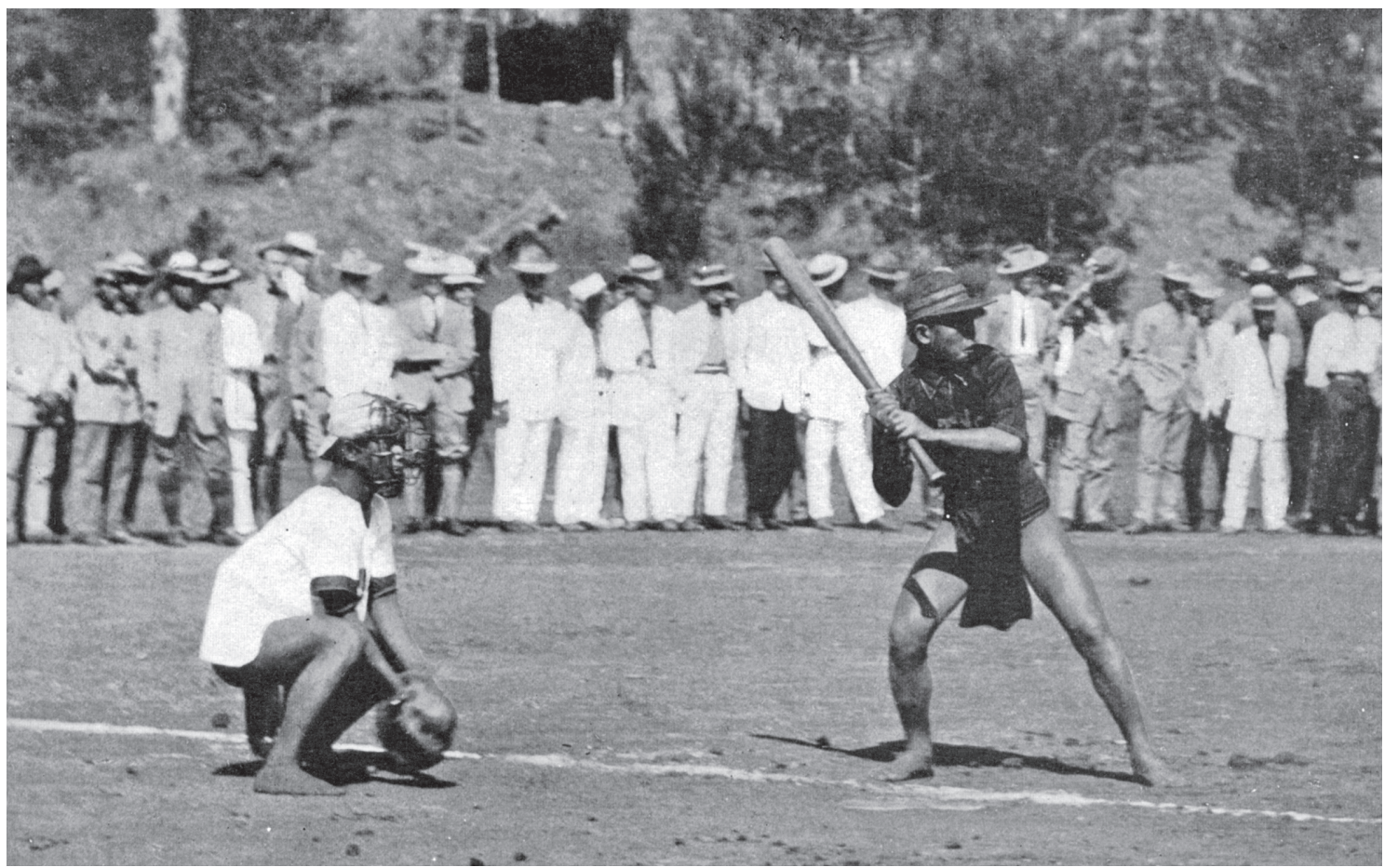

Baseballtransferred the nationalistic sentiments of the Filipinos against the Japanese rather than the United States. (Photo: From Dean C. Worcester, "The Non-Christian Peoples of the Philippine Islands," National Geographic, 24: 11 (November 1913), pp. 1252, 1255) 
quent lack of activity for most Americans has caused alarming rates of obesity in the country to the detriment of the health care system. Although few adults continue to practice sport, nearly all children are exposed to sporting practices as a means to inculcate the American cultural values early in life (Gems \& Pfister 2009).

The roots of commercialized sport began more than 150 years ago in 1852, when the rowing teams of Harvard and Yale accepted an invitation from a railroad company to compete at a lake where it had built a resort. The winner received a $\$ 500$ pair of silver oars; but the real intent of the railroad company was to use the athletic event to publicize its resort and to gain paying customers for the railroad. Thus began the commercialization of American intercollegiate sport. Within a generation American colleges wholeheartedly embraced the concept of sport as a business, luring paying customers to large urban arenas, where they could witness sport spectacles. Sport became a means to tie graduates of the various schools to the colleges and universities by maintaining their interest in the school athletic teams. The graduates, known as alumni, are feted annually at the schools in lavish parties and they provide monetary donations, not only for academic purposes, but for the betterment of their sports teams. Today the top football and basketball coaches' salaries greatly exceed that of full professors and the university presidents and vast sums of money are spent on athletic facilities.

By the end of the nineteenth century the secondary schools had copied the elitist sport system of the colleges that sought only the best players for its teams to represent it against its academic rivals. Today it is even commonplace at the junior high school level, where the best

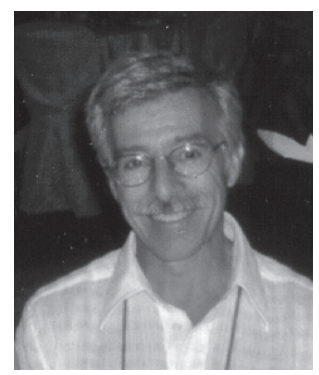

BY

GERALD R. GEMS

athletes are chosen for several teams each season to compete against all the other junior high schools in the area, which form a league for such purposes.

Adult administrators in the colleges and high schools began taking control of the previously student organized teams and events by the late nineteenth century. By incorporating sport and physical education within the school curriculum they were able to gain not only greater control over the students' leisure activities; but also the revenue derived from the contests. Under the leadership of trained supervisors, physical education teachers, and coaches the students were taught to play in a particular way, which reinforced the core values of American society.

By the late nineteenth century philosophers, psychologists, and educators held the idealistic belief that play, properly taught, could teach desirable values and elevate practitioners to a higher level of civilization. They hoped that competition, the basis for both sport and the capitalist economic system, would wean students from the radical sympathies of many Europeans. The national sport of baseball, which combined elements of teamwork and individualism, taught players to sacrifice for the good of the whole, as in a democracy. Most importantly for the employers, sport taught deference to authority; for arguing with a game official might cause ejection 
from the contest (Cavallo, 1981, Gems, 1997, Lester, 1995, Pruter, 2003, p. 47-72). ${ }^{1}$

Such lessons were first enacted as early as 1879 when the U.S. government opened the first of many residential schools for the children of the defeated American Indian tribes. At the schools Indians were forced to adopt white, Anglo norms by cutting their long hair, speaking English, learning the white sport forms, and developing vocational skills that would prepare them for jobs in the capitalist workforce. American Protestant missionaries had adopted similar strategies in the Hawaiian Islands as early as the $1840 \mathrm{~s}$, where they initiated residential schools and introduced the students to the Ame-

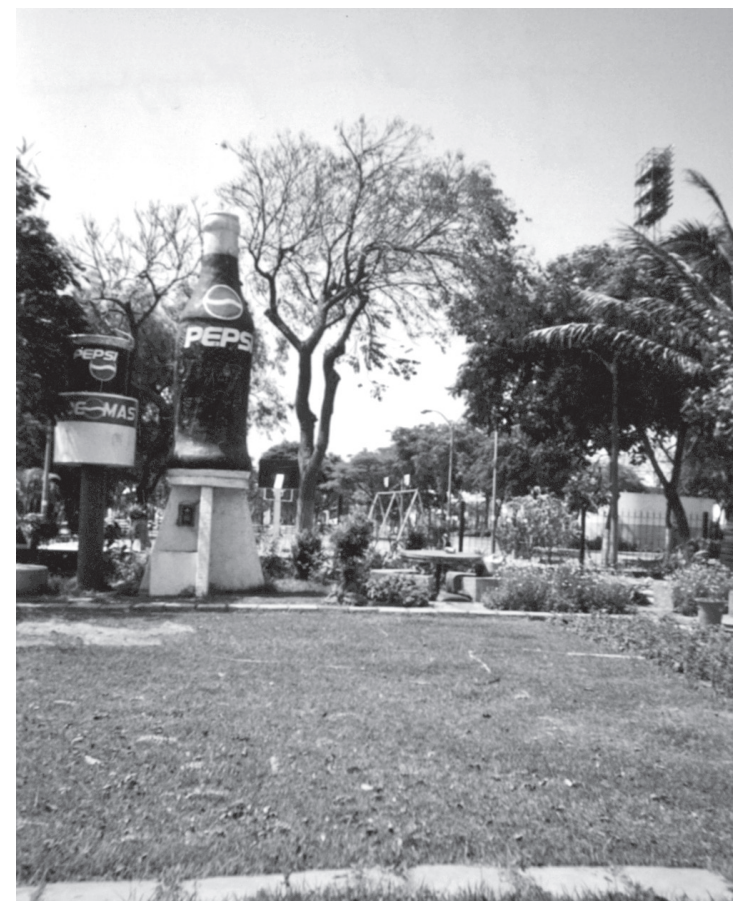

Pepsi bottle in Peru. The commercialization of American products accompanied the spread of sport (Photo: Gerald Gems). rican game of baseball (Adams, 1995, Bloom, 2000, Gems, 2006, p. 67-70, Hoxie, 1989).

The strategy of using sport as education also proved effective when applied to the children of immigrant families that flooded American shores between 1880 and 1920. Before labor activists won social, economic, and health benefits through strikes, arbitration, and negotiation throughout the nineteenth and twentieth centuries, employees worked long hours for minimal wages, six days a week, without any assurances of medical care if disabled or relief for one's family if they died in an industrial accident, which were commonplace. Working class families, which included the vast majority of European ethnic immigrants, relied upon a full complement of family labor for sustenance. The employment of as many family members as possible served as some protection if the father, the chief bread winner, became unemployed or injured. Multiple paychecks might even allow a family to save some money for a crisis or, hopefully, the eventual purchase of their own home, which was the major aim of many families.

Nativists and middle class Americans, however, feared the potential sociopolitical power of the exploited laborers, who might succumb to the anarchist, socialist, or communist movements then popular in many of their European homelands. In 1899 the city supervisor for compulsory education in Chicago, a largely immigrant city, stated that

"We should rightfully have the power to arrest all these little beggars, loafers and vagabonds that infest our city, take them from the streets and place them in schools where they are compelled to receive education and learn moral principles... measures cannot be taken any too soon... which will make the control of this class easier of solution". ${ }^{2}$ 
By 1918 all state governments had enacted laws to acculturate youth to the value system of the dominant mainstream culture. They first passed child labor laws that removed children from the workplace. They then required compulsory education, followed by mandatory physical education that taught the American capitalist values through sports and games, providing important lessons for even non-English speakers in the schools, parks, playgrounds, and settlement houses (social agencies situated within the ethnic neighborhoods) (Carson, 1990, Gems, 2008, p. 174-187).

As immigrant ethnic youth increasingly attended the public schools after the turn of the twentieth century they gained more exposure to American sports and games. The best high (secondary) school athletes were even awarded with athletic scholarships to the universities, which provided free room, board, and tuition in exchange for representing the school in its athletic competitions against rival institutions. The continued overemphasis on sport within the American universities represents a marked departure from higher education in Europe and other regions of the world.

American youth did not need to attend the university to gain greater prestige, social or economic capital however. The professionalization of American sports offered ample opportunity for athletes to gain remuneration for their physical skills without the necessity of a college degree. Their habitus revolved around physical rather than intellectual prowess. Boxing and pedestrianism were the first to offer professional opportunities, and baseball greatly expanded such possibilities as early as the 1860 s. American football, basketball, and cycling provided even more opportunities by the end of the century, and even female professional athletes appeared in baseball, cycling, and pedestrian competitions. Ethnic sport heroes, the children of immigrants, could be found throughout the nation, reinforcing the belief in the American meritocracy. Even the ethnic groups much opposed to sport as a waste of time, such as the Jews, who valued education, or the Italians, who valued family labor, acquiesced when their sons brought home more income from their athletic pursuits than their industrial wages (Gems et al. 2008, p. 198-203).

Babe Ruth, the son of German immigrants and raised in an orphanage, became perhaps the greatest American athletic icon as a baseball player. By the end of the 1920s he earned a greater salary than the president of the United States. Ruth represented the belief that anyone of ability could fulfill the American dream without the benefit of wealth, education, or social class.

When the Great Depression of the 1930s should have fueled American doubts about capitalism, sport continued to provide a means of sustenance for many suffering families as newspapers sponsored bowling tournaments with lucrative cash prizes for men and jewelry for women; while local gamblers and neighborhood bar owners organized softball leagues for wagers and money prizes in many working class neighborhoods. The middle class value of competition merged with the working class value of physicality to maintain a belief in the commercial American economy. Such entrepreneurial ventures, combined with the cooptation of the labor unions within the political system provide some explanation as to why there has never been a strong socialist movement or even a strong third political party to oppose the Democrats or the Republicans within the United States (Gems, 2001, p. 43-58, Gems et al., 2008, p. 238-241). 


\section{AMERICAN FOREIGN POLICY}

Americans began exporting the ideology of liberty, equality, democracy, and meritocracy as soon as they acquired colonial possessions in the aftermath of the Spanish-American War of 1898. At the Chicago World's Fair of 1893 Professor Frederick Jackson Turner presented his frontier theory, claiming that the experiences of settling the American wilderness had created an exceptional people who were democratic, tough, independent, self-reliant, and resourceful. He lamented that the closing of the frontier might not afford such qualities to future generations of Americans. Frederic Paxson, a student of Turner's and a president of the scholarly association that would become the Organization of American Historians, later declared sport to be the new frontier, which might produce similar character building qualities (Bogue, 1998, Paxson, 1917, p. 143-168).

The Spanish-American War greatly extended the boundaries of the American frontier, and the belief in American exceptionalism, and the white man's burden assumed the stature of a religious mission. Josiah Strong, an influential Protestant minister and author, declared that Anglo-Saxons had produced the "purest Christianity and the highest civilization," which made them "divinely commissioned to be ... (their) brother's keeper” (Pratt, 1959, p. 5). Great debate ensued in the nation and in the Congress over the propriety of a democracy obtaining imperial colonies; but the government ultimately sided with Senator Albert Beveridge, who stated that

"We will not repudiate our duty in the Orient. We will not renounce our part in the mission of our race, trustees under God, of the civilization of the world. And we will move forward to our work, not howling out regrets like slaves whipped to their burden, but with gratitude to a task worthy of our strength, and thanksgiving to Almighty God that he has marked us as His chosen people, henceforth to lead in the regeneration of the world" (Jacobson, 2000, p. 226).

Such presumption and lofty rhetoric continued to shape American foreign policy over the remainder of the twentieth century and sport played an important, though more subtle role in the promotion of the American culture, power, and economy.

\section{AMERICAN SPORT IN THE PACIFIC}

The Americans had already attempted to introduce capitalism, Protestantism, and western sport forms to both Japan and China in the late nineteenth century with limited success. Both European and American military units forced the Asian nations to open their vast markets to capitalist goods; but they found few converts to their religious missions. Sport fared somewhat better, as the Japanese, in particular, adapted baseball to their own cultural norms. The Japanese used baseball as a racial barometer to measure their victories against visiting American teams and Japanese teams traveled to Hawaii and the United States in search of competition. American college and professional teams also traveled to Japan into the 1930 s, with such trips hailed as goodwill excursions meant to ameliorate relations between the two countries. In 1934, however, Moe Berg, one of the participants on the American team, used the occasion to film Tokyo installations for the U.S. government, which later proved helpful in its World War II bombing campaign. The competitions proved heated at times, and as early as the 1930s the Japanese clamored for a true World Series (as the Americans dubbed their national champi- 
onship). Japanese nationalism and racial anxieties were finally vindicated when it won the first World Baseball Classic tournament in 2006, and then repeated as the champion in 2009 (Gems, 2006, p. 17-44).

American merchants and plantation owners had organized a successful coup against the Hawaiian monarchy in 1893, supported by the U.S. diplomat and a contingent of marines. The United States formally annexed the territory in 1898 during the Spanish-American War. Sport served as a means of social control among a polyglot labor force that included Chinese, Japanese, Portuguese, Filipino, and native Hawaiian residents, as well as military units comprised of African Americans. Plantation owners organized baseball leagues as a means to provide wholesome recreation as an alternative to drinking and to insure productive workers. The baseball leagues in Honolulu included the African American teams and offered an experiment in racial integration long before such opportunities reached the mainland. Moreover, the conscription of

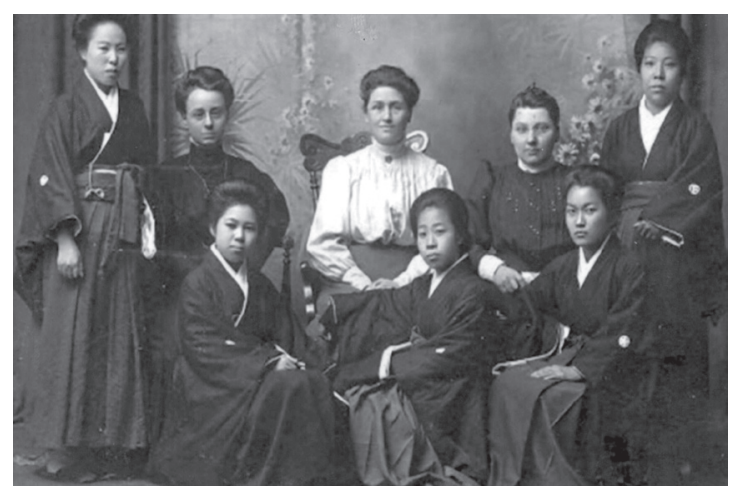

Protestant missionaries taught American cultural values to their Japanese students (Photo: From Dean C. Worcester, "The Non-Christian Peoples of the Philippine Islands," National Geographic, 24: 11 (November 1913), pp. 1252, 1255). the best Hawaiian athletes for the Olympic team as early as 1912 allowed the United States to present an international image of racial inclusion, harmony, and democracy when the realities for most non-whites in America were decidedly unequal (Gems, 2006, p. 67-81, Kinzer, 2006, p. 9-34).

The Americans gained the Philippines by conquest in the Spanish-American War; although the Filipino revolutionary army had nearly secured victory by the time the US forces arrived. American soldiers began teaching baseball and boxing to the Filipino populace even before the U.S. government sent school teachers to the archipelago in 1901. Under the leadership of Governor-General Cameron Forbes, a former football coach at Harvard University, the American government constructed a physical education and sport program in the schools even more comprehensive than that fashioned in the American states. Both boys and girls were required to take physical education classes, where they learned to play the American sports and inculcate their inherent value systems. Students learned to compete in local, regional, and national championships in a wide array of sports. Americans combated Filipino nationalism and an ongoing guerrilla war over their occupation of the islands by channeling such sentiments against the Japanese, American rivals in the Pacific. Japanese baseball teams began arriving in the Philippines as early as 1905, and the international matches assumed the role of surrogate warfare. An American reported that "the rivalry was spirited. Once or twice it bordered on bitterness. In short the game was for blood. Having defeated a white foe in war (Russo-Japanese War of 1904-05), no doubt the Japs could not brook defeat by their neighboring islanders." When the Filipinos tri- 
umphed "Bedlam broke lose, Japan was whipped, and the Cebu men became heroes" (Gems 2006, p. 44-8, Kinzer, 2006, p. 35-42, Wooley, 1913, p. 313-14)

The U.S. government employed the Young Men's Christian Association (YMCA), a proselytizing Protestant organization, to direct public education, prepare a recreation manual, and train playground supervisors. The Manila Carnival, a commercial fair, was transformed into an athletic spectacle under the guidance of the YMCA. By 1912 it included national championships and competition in at least thirteen sports. Athletic invitations to Japan, China, and other Asian nations soon transformed the event into a grand spectacle known as the Far East Olympics. American baseball teams continued to travel to the Philippines until the advent of World War II, reasserting American values through sport. Filipinos would even adopt the American game of basketball as their national sport (Gems 2006, p. 44-81).

\section{AMERICAN SPORT IN THE CARIBBEAN REGION}

The United States made similar impositions in the Caribbean in the aftermath of the SpanishAmerican War. Like the Philippines, the Americans disregarded the successes of the largely black revolutionary army in Cuba. Internal issues in Cuba had precipitated the war, when the US newspapers raised alarms about the Spanish treatment of the island inhabitants. The explosion of an American warship in Havana harbor provided a ready excuse for the hostilities. The American government assured the Cubans of their independence; but the handpicked president was a Protestant American citizen, and the US secured a naval base on the island, which it continues to hold more than a century later. Protestant missionaries and the YMCA soon arrived to try to convert the already Catholic inhabitants and to impose their own brand of Christianity. When the Cubans started an insurrection in 1906 the Americans returned to occupy the island, and banned a black Cuban political party to prohibit blacks from gaining power and influence. American businessmen controlled much of the Cuban economy, and Havana became the illicit playground for Americans seeking pleasures deemed too unseemly in the United States (Gems, 2006, p. 82-94, Healy, 1988, p. 203, p. 208). ${ }^{3}$ Cubans claimed that they had "exchanged the Spanish yoke for an American yoke."4

Sport provided one of the few means for $\mathrm{Cu}$ ban opposition, as nationalism and race issues became apparent in the athletic confrontations. Cubans challenged the Americans in football, basketball, and track and field; but they had particular success in baseball. American professional teams traveled to Cuba to train in the warm weather; but when the Cuban teams inflicted too many losses on the best American contingents, the president of the American League prohibited travel to the island in 1911. The racial hierarchy was further reinforced in 1915 when Havana served as the site for the Jack Johnson - Jess Willard heavyweight championship fight. Johnson, an African-American, had won the title in 1908 and outraged whites with his blatant disregard of the racially segregated norms. He was forced to flee the country or be sent to prison for his sexual relations with white women. Johnson's suspicious loss restored white supremacy in the United States for another twenty years (Gems, 2006, p. 92, Roberts, 1983, p. 199-203).

By the 1930s the American government supported a Cuban military dictator, Fulgencio Batista. Despite the public promotion of democracy and idealistic humanitarian values by 
American government officials, the United States often supported authoritarian regimes that safeguarded its commercial interests. Batista's despotic rule opened Cuba to American gangsters and ultimately resulted in his overthrow by the communist forces of Fidel Castro in 1958. Similar American ventures backfired on the American government elsewhere in the Caribbean (Kinzer, 2006, p. 89).

The Cubans had taught the Dominicans to play baseball, and the sporting relations increased after American forces landed in the country in 1905 to take control of the customs house and pay the country's debts to American financiers. When the Dominicans refused to accept an American puppet for their president, American marines established a military government until 1924. The Dominicans engaged in a guerrilla war, and the Americans used baseball as a pacifier and a means of social control (Gems, 2006, p. 116-119). As early as 1913 the U.S. minister wrote to the American secretary of state:

"that the game of baseball is being played and supported here with great enthusiasm. The remarkable effect of this outlet for the animal spirits of the young men, is that they are leaving the plazas where they were in the habit of congregating and talking revolution and are resorting to the ball fields where they become wildly partizen (sic) each for his favorite team. The importance of this new interest ... should not be minimized, It satisfies a craving in the nature of the people for exciting conflict, and is a real substitute for the contest in the hill-sides with rifles, if it could be fostered and made important by a league of teams ... it well might be one factor in the salvation of the nation" (Klein, 1991, p. 110).
By the 1920s a dozen American companies controlled $75 \%$ of the sugar plantations in the Dominican Republic and $95 \%$ of the sugar went to the United States. The installation of Rafael Trujillo as dictator by the end of the decade assured close ties with the American government (Gems, 2006, p. 118-19). The development of the Dominican baseball leagues would eventually supply a steady stream of cheap labor to the American professional teams. In 2008 the Dominicans accounted for more players in the American professional leagues than any state except California. $^{5}$

Like Cuba, baseball arrived in Puerto Rico even before the American troops took over the islands in 1898. Unlike the Cubans, the Puerto Ricans never regained their independence and remain an American territory with commonwealth status. The American occupation spawned an unsuccessful attempt to convert the Catholic population to Protestantism and to replace Spanish with the English language. The inculcation of baseball and other American sports proved more successful; however, not always with the results desired by the Americans. The Puerto Ricans did not accept a docile citizenship. In 1948 Puerto Rico sent its own Olympic team to London, separate from the American squad. Two years later Puerto Rican nationalists made an unsuccessful assassination attempt on the U.S. president. In 1954 they attacked the U.S. Congress, resulting in a gun battle that killed three participants and the wounding of five congressmen. While Puerto Ricans maintain a vibrant independence party today, they now challenge the United States on the athletic field, content to win occasional victories in basketball and baseball. Its numerous baseball players in the American professional leagues return much 
needed revenue to the island and serve the populace as cultural heroes (Gems, 2006, p. 99-114, Kinzer, 2006, p. 44-45, p. 92). ${ }^{6}$

\section{AMERICAN SPORT IN EUROPE AND ABROAD}

Americans have made a concerted effort to spread their democratic and capitalist ideology throughout the world, and sport has served as a more subtle means to do so. The American government developed plans as early as the 1920 s to implement sport for commercial benefit through the Olympic Games. The initial confrontation with fascist Germany came not on the battlefield, but in the boxing ring, as American media persisted in characterizing the Joe Louis - Max Schmeling bouts of the 1930s as a contest between good and evil, even though Schmeling was not a Nazi. It is estimated that $60,000,000$ Americans heard the fights on radio, nearly half of the entire population (Dyreson, 2008, p. 268283, Margolick, 2005, p. 150, p. 289). ${ }^{7}$

In the aftermath of World War II sport served as a surrogate form of battle known as the Cold War once the Soviet Union entered the Olympic Games in 1952. Both sides tried to prove the superiority of their ideology. John Foster Dulles, U.S. Secretary of State during that era, declared that "for us there are two sorts of people in the world. There are those who are Christians and support free enterprise, and there are the others" (Kinzer, 2006, p. 215). ${ }^{8}$ The American ideology became suspect when black track stars staged a protest with the black power salute before an international audience at the 1968 Games. Their actions drew attention to the disparity between American rhetoric and American practices. Their actions were further enhanced by the ongoing diatribes of Muhammad Ali, the heavyweight boxing champion who became a global icon as he challenged the precepts of patriotism and nationalism in the United States. His stance in opposition to the Viet Nam war forced American society to confront its most cherished values in the declared civil rights that guaranteed the freedoms of speech, religion, and opportunity to all. As blacks and an increasing number of women, as well as homosexuals began to question the purported equality in American society, soldiers in Viet Nam taught children how to play baseball (Dennison, 2009, p. 43-45, Schandler, 2004 , p. $18-24){ }^{9}$

\section{CONCLUSION}

The American pattern of introducing its sport forms as a means to teach an inherent value system continued throughout the remainder of the twentieth century. The introduction of American football and baseball to Europe could not displace the entrenched devotion to soccer; although basketball and volleyball, two sports created by the Protestant YMCA, have found a global reception.

The American efforts to spread baseball throughout Asia and the Caribbean brought unintended and unanticipated consequences to the American hegemony. Today professional players from Japan, South Korea, Taiwan, the Dominican Republic, Puerto Rico, Venezuela, Panama, Nicaragua, Cuba, Mexico, and a dozen other countries earn their salaries in the U.S. leagues, threatening to supersede the American players. ${ }^{10}$ The baseball team owners now seek to train boys in Africa, perhaps a new source of cheap labor for the future; while U.S. troops continue to teach American games and American ideology to the children of the Mideast and Asia.

Sport can be a more subtle means than guns or war to teach particular values; but if all else fails the U.S. has shown its willingness to impose its political and economic will by force. Past Se- 
cretary of State Henry Kissinger stated that "I don't see why we need to stand by and watch a country go Communist due to the irresponsibility of its own people." He referred to the popular election of a socialist president, Salvador Allende, in Chile in 1970. The U.S. soon assisted in a coup which installed the dictator Augustin Pinochet in 1973. The Chilean transition proved only one of fourteen governmental overthrows orchestrated by the United States since the 1890s (Kinzer, 2006, p. 170-194). Sport has been a less violent and less deadly alternative as a means to promote American commerce and American cultural values.

\section{REFERENCES}

Adams D. W. (1995). Education for Extinction: American Indians and the Boarding School Experience, 1875-1928. Lawrence, KS: University of Kansas Press.

Bloom J. (2000). To Show What an Indian Can Do: Sports at Native American Boarding School. Minneapolis: University of Minnesota Press.

Bogue A. G. (1998). Frederick Jackson Turner: Strange Roads Going Down. Norman: OK: University of Oklahoma Press.

Carson M. (1990). Settlement Folk: Social Thought and the American Settlement Movement, 18851930. Chicago: University of Chicago Press.

Cavallo D. (1981). Muscles and Morals: Organized Playgrounds and Urban Reform, 1880-1920. Philadelphia: University of Pennsylvania Press.

Dennison R. (2009). The Vietnam Rollers Play Ball! Vietnam, April, 43-45.
Dyreson M. (2008). Johnny Weissmuller and the Old Global Capitalism: The Origins of the Federal Blueprint for Selling American Culture to the World. International Journal of the History of Sport, 25:2, 268-283.

Gems G.R. (1997). Windy City Wars: Labor, Leisure and Sport in the Making of Chicago. Lanham, MD: Scarecrow Press.

Gems G. (2001). Welfare Capitalism and BlueCollar Sport: The legacy of labour unrest. Rethinking History, 5:1, 43-58.

Gems G. R. (2006). The Athletic Crusade: Sport and American Cultural Imperialism. Lincoln, NE: University of Nebraska Press.

Gems G. R., Borish L. J., \& Pfister G. (2008) Sports in American History: From Colonization to Globalization. Champaign, IL; Human Kinetics.

Gems G. \& Pfister G. (2009). Understanding American Sport. London: Routledge.

Healy D. (1988). Drive to Hegemony: The United States in the Caribbean, 1898-1917. Madison, WI: University of Wisconsin Press.

Hoxie F. E. (1989). A Final Promise: The Campaign to Assimilate the Indians, 1880-1920. New York: Cambridge University Press.

Jacobson M. F. (2000). Barbarian Virtues: The United States Encounters Foreign Peoples at Home and Abroad, 1876-1917. New York: Hill and Wang. 
Kinzer S. (2006). Overthrow: America's Century of Regime Change from Hawaii to Iraq. New York: Henry Holt \& Co.

Klein A. M. (1991). Sugarball: The American Game, the Dominican Dream. New Haven, CT: Yale University Press.

Lester R. (1995). Stagg's University: The Rise, Decline, and Fall of Big-Time Football at Chicago. Urbana, IL: University of Illinois Press.

Margolick D. (2005). Beyond Glory: Joe Louis vs Max Schmeling, and a World on the Brink, New York: Alfred A. Knopf.

Paxson F. L. (1917). The Rise of Sport. Mississippi Valley Historical Review, 4, 143-168.

Pratt J. W. (1959). Expansionists of 1898: The Acquisition of Hawaii and the Spanish Islands. Gloucester, MA: Peter Smith.

Pruter R. (2003). Chicago High School Football Struggles, the Fight for Faculty Control, and the War against Secret Societies, 1898-1908. Journal of Sport History, 30:1, 47-72.

Roberts R. (1983). Papa Jack: Jack Johnson and the Era of White Hopes. New York: Free Press.

Schandler H. Y. (2004). Return to the Street Without Joy. Vietnam, December, 18-24.

Wooley M. (1913).'Batter Up' in the Philippines. Outdoor World and Recreation, May 1913, 313-14.

\section{NOTES}

1. Psychologist G. Stanley Hall preached his recapitulation theory of play, which proposed that civilization levels could be traced through the nature of a society's games. His pupil, John Dewey, promoted the pragmatic philosophy of experimentation, trial and error, and practical application and sporting practices allowed for such an approach.

2. Theodore J. Bluthardt quoted in William R. Harper, chairman, Report of the Educational Commission of the City of Chicago (Chicago, 1899), 163-4

3. By 1918 the US accounted for $76 \%$ of Cuban imports and $72 \%$ of its exports.

4. Memorandum for the Chief of Staff, September 23, 1908, US National Archives, Cuba, RG 395.

5. See http://www.baseball-almanac.com/players/birthplace. php?y=2008 (March 9, 2009)

6. See also http://www.baseball-almanac.com/players/birthplace.php?y=2008 (March 9, 2009)

7. The winter Games of 1928 were held in Lake Placid, New York and the 1932 Games were staged in Los Angeles; see Dyreson, 2008, p. 268-283. Estimates of the radio audience are found in Margolick, 2005, p. 150, p. 289.

8. John Foster Dulles in Kinzer, 2006, p. 215.

9. Dennison (2009) indicates that such instructional efforts continue with student exchange groups today.

10. See http://www.baseball-almanac.com/players/birthplace. php?y=2008 (March 9, 2009) 